\title{
Expression Pattern of Ethylene-Related Genes in Response to Preharvest Chemical Treatments during Development and Ripening of Mangosteen Fruit (Garcinia mangostana L.)
}

\author{
Ladawan LERSLERWONG ${ }^{1,2,4, *}$, Saithip THIPPAN ${ }^{1}$, \\ Adirek RUGKONG ${ }^{1,4}$ and Wachiraya IMSABAI ${ }^{3,4}$
}

\author{
${ }^{1}$ Faculty of Natural Resources, Department of Plant Science, Prince of Songkla University, \\ Songkhla 90112, Thailand \\ ${ }^{2}$ Pest Management Biotechnology and Plant Physiology Laboratory, Faculty of Natural Resources, \\ Department of Pest Management, Prince of Songkla University, Songkhla 90112, Thailand \\ ${ }^{3}$ Faculty of Agriculture at Kamphaeng Saen, Department of Horticulture, Kasetsart University, \\ Kamphaeng Saen Campus, Nakhon Pathom 74130, Thailand \\ ${ }^{4}$ Postharvest Technology Innovation Center, Commission of Higher Education, \\ Bangkok 10400, Thailand
}

('Corresponding author's e-mail: ladawanllw@yahoo.com)

Received: 27 March 2019, Revised: 6 July 2019, Accepted: 27 August 2019

\begin{abstract}
The expression of ethylene associated genes based on development stage from fruit set until harvest in mangosteen has not been studied yet in some previous studies. The objective of this study was to investigate the expression pattern of genes involved in ethylene biosynthesis, Gm-ACS, and Gm-ACO, and perception, Gm-ETR, from the stages of fruit set (Period I), fruit development (Period II), and maturation until ripening or harvesting (Period III). The results showed that ethylene biosynthetic genes on the Gm-ACO gene were correlated with ethylene production's climacteric pattern. Gm-ACO was upregulated at the beginning of the fruit set and then decreased. Fruit at age $2-10$ weeks after anthesis showed a decrease in the Gm-ACO gene's mRNA levels. Then, Gm-ACO expression re-appeared and increased at the fruitage $11-12$ after the fruit set. At the harvest-stage, the fruit showed down-regulation at the lowest level of the Gm-ACO expression. Ethephon treatment at or beyond $24 \mathrm{~h}$ (threshold time) increased the mRNA levels of Gm-ACS, Gm-ACO, and Gm-ETR. In contrast, the 1-Methylcyclopropene (1-MCP) treatment under the threshold time resulted in undetectable expression in all ethylene-related genes. These data would be beneficial to elucidate the molecular mechanisms in the mangosteen fruit ripening process. In addition, preharvest application of ethephon or 1-MCP can induce or inhibit the gene expression of ethylene biosynthesis and perception.
\end{abstract}

Keywords: Mangoseteen, Ethylene, Gene expression, Ethephon, 1-Methylcyclopropene

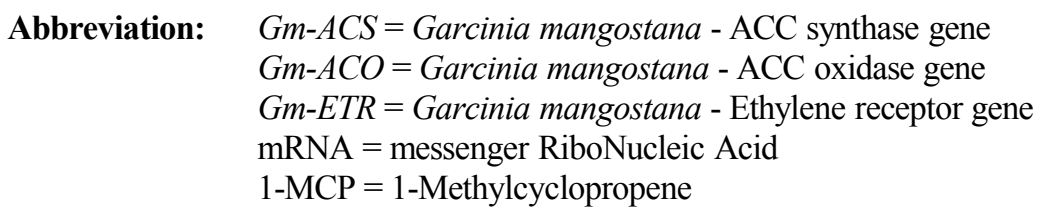




\section{Introduction}

Mangosteen (Garcinia mangostana L.) is the most praised tropical fruit belonging to the family of Clusiaceae or alternate name Guttiferae, which has approximately 50 genera and 1,200 species, with 8 genera producing edible fruit. Commercial production for export occurs in Southeast Asian countries, including Thailand, Malaysia, and Indonesia [1]. Thailand is the leading producer and exporter of mangosteen globally. In 2018, Thailand produced 185,000 tons of mangosteen, and its export was valued at \$254 million [2]. The fruit is typically consumed fresh or in a partially frozen state, and its pericarp is extracted for xanthones, which have been reported to have anti-cancer, anti-inflammatory, anti-oxidant, anti-bacterial, and anti-viral properties $[3,4]$. Therefore, the current demand for mangosteen and its pericarp has also increased gradually.

Previous studies showed evidence that mangosteen fruit's actual climacteric fruit starts since the pre-harvest period, but the exact time of climacteric ethylene peak remained unknown. The cumulative growth in fruit weight of mangosteen fruit is portrayed by a single sigmoid pattern of ethylene production and fruit weight [5] in parallel with the fruit of plant involving 3 distinct stages: fruit set, development, and ripening as mentioned by [6].

The ethylene production was highest in the $1^{\text {st }}$ week of the fruit set (Period I) and then decreased from early fruit development to non-detectable levels at 9 weeks, with rapid growth at Period II. Ethylene production re-appeared 3 weeks before harvest and decreased slightly at the harvest stage, in which fruit maturation and ripening stage occurred (Period III). In this last stage, there are 7 maturity and ripening stages, $0-6$, separated by the coloration of pericarp: the maturity of fruit on tree begins at yellowishwhite with light green (stage 0), light greenish-yellow with 5 - $50 \%$ scattered pink spots (stage 1 or harvest stage), light greenish-yellow with 51 - $100 \%$ scattered pink spots (stage 2), reddish-pink (stage 3), red to reddish-purple (stage 4), dark purple (stage 5) and purple-black (stage 6) [7].

The ripening of mangosteen could be hastened and delayed when applying ethephon (2-chloroethyl) phosphonic acid) and 1-MCP on detached fruit before harvesting. Ethephon is a gaseous plant growth regulator that acts by releasing ethylene, directly influencing many aspects of physiological processes, including maturation, senescence, and abscission. Ethephon is used to manipulate fruit development and storage quality in many commodities, including fruits, vegetables, cereals, and oilseed crops [8]. However, ethephon is the only compound registered for improving the color, hastening maturity, and stimulating abscission at considerably lower use rates due to its residues, which are below legal limits [9]. While 1-MCP as a chemically nontoxic substance is environmentally friendly and harmless to human health, animals, and the environment, it has been approved for use in the United States by The United States Environmental Protection Agency (USEPA). 1-MCP is an innocuous gas applied at very low rates, which inhibit ethylene action by blocking the ethylene receptors. This substance has been employed widely to delay the ripening and maintain horticultural commodities quality [10]. However, the success in controlling the fruit ripening of mangosteen by pre-harvest chemicals depends on the right time of the climacteric peak, at stage 0 or pericarp uniform yellowish-white [5].

The process of ethylene biosynthesis in higher plant involves 3 steps: 1) the conversion of methionine into S-Adenosyl Methionine (SAM) activated by enzyme SAM synthetase, 2) the further cleavage of SAM into 1-amino cyclopropane-1-carboxylic acid (ACC) and 5'methyl thioadenosine by enzyme ACC synthase (ACS), and 3) the conversion of ACC to form ethylene, which involves oxidization by the enzyme ACC oxidase (ACO). The last 2 steps are known to mediate the ethylene biosynthesis pathway by enhancing the activity of the principal enzymes ACS and ACO, which also enhances ethylene production [11]. This step involves an interplay of induction and inhibition of the expression of different genes coded for ACS and ACO and ethylene receptors (ETR). The isolation of ethylene-related genes during fruit ripening has resulted in significant knowledge about ethylene biosynthesis, perception, and response [12]. The only one report has been published in RNA-seq analysis of mangosteen fruit ripening [4]. Nevertheless, little published work has appeared on the climacteric of ethylene in attached fruit or at the preharvest period, especially regarding ethylene-related genes' expression during fruit development and ripening. At the molecular level, expression of ethylene 
http://wjst.wu.ac.th

associated genes based on development stage from fruit set until harvest in mangosteen has not been studied yet.

Hence, this study aimed to investigate the expression patterns of 3 genes involved in the ethylene biosynthetic pathway, Gm-ACS and Gm-ACO, and 1 ethylene perception gene Gm-ETR, during the fruit developmental stage of mangosteen. The expression of these ethylene related genes after chemical treatments was also examined. Understanding these genes' expression patterns would be beneficial to devise an accurate application of chemicals for controlling the ripening of mangosteen.

\section{Materials and methods}

\section{Fruit materials}

The tissue samples were collected from 12 years old mangosteen trees growing in the Faculty of Natural Resources research station, Prince of Songkla University, Songkhla Province, Southern Thailand. The sampling was performed from 14 days of the fruit set to harvest, from May to July 2010, at the weekly interval, throughout the development of mangosteen fruit. This sampling was the same set of the experiment reported in Lerslerwong et al. [5]. In preharvest chemical treatment, sampling was performed before treatment, after $24 \mathrm{~h}$ treatment and at harvest date. The fruit was harvested at stage 1; light greenish-yellow with $5-50 \%$ scattered pink spots. After the harvest, the fruit was brought to the laboratory within $2 \mathrm{~h}$ after harvest.

\section{Preharvest chemical treatments}

The preharvest 2-chloroethanephosphonic acid (ethephon) and 1-MCP fumigated treatments were applied at approximately 10 weeks after anthesis (fruit at stage 0; pericarp uniformly yellowish-white or with a light green tinge or grayish spotting). Intact fruits were soaked in a solution of ethephon (48 \% a.i.) at $500 \mathrm{~mL} \mathrm{~L}^{-1}$, and $0.1 \% \mathrm{v} / \mathrm{v}$ LATRON® CS - 7 adjuvant (ZAGRO (Thailand) Ltd., Thailand) was added. Ethephon soaking of intact fruit on the tree was performed to avoid leaf abscission, which causes the dispersion of solution spray. The soaked fruit with ethephon was bagged in closed $15 \times 28 \mathrm{~cm}$ lowdensity polyethylene (LDPE) with density $0.92 \mathrm{~g} \mathrm{~cm}^{-3}$ bags for $24 \mathrm{~h}$. For preharvest 1-MCP treatment, the whole fruit tree was fumigated with one-eight 1 -MCP tablets $(0.15 \mathrm{~g})$. 1-MCP express $0.19 \%$ per pellet $(1.2 \mathrm{~g})$, AnsiP ${ }^{\circledR}$; Lytone Enterprise Inc., Taiwan. Each tablet piece was wrapped in moist cotton and then placed in the closed polyethylene bags in the same manner as in ethephon treatment. On the following day, the bottom of the bag was opened with a cutter for ventilation. The fruit without any of these treatments was used as a control.

\section{RNA extraction and cDNA synthesis}

The mangosteen fruit pericarps were ground in liquid nitrogen and stored at $-80{ }^{\circ} \mathrm{C}$ until they were used for RNA extraction. Total RNA was isolated from the frozen material using the CTAB method. The $1.5 \mathrm{~mL}$ microcentrifuge tubes with $0.25 \mathrm{~g}$ of ground samples were added to $1,200 \mu \mathrm{L}$ of $65^{\circ} \mathrm{C}$ prewarmed CTAB RNA extraction buffer (100 mM Tris-HCl, pH 8.2, 2 \% CTAB, $2 \mathrm{M} \mathrm{NaCl}$, and $25 \mathrm{mM}$ EDTA). An equal amount of PVPP was then added. $\beta$-mercaptoethanol ( $1 \mathrm{~mL}$ per $50 \mathrm{~mL}$ extraction buffer) was added to the extraction buffer before using. The samples were mixed thoroughly and incubated at $65{ }^{\circ} \mathrm{C}$ for $10 \mathrm{~min}$ and then were shaken by vortex mixer for $10 \mathrm{~min}$ before centrifugation at $6,500 \mathrm{rpm} 4{ }^{\circ} \mathrm{C}$ for $30 \mathrm{~min}$. The aqueous phase was collected in a new $1.5 \mathrm{~mL}$ microcentrifuge tube and extracted twice with an equal volume of cool chloroform: isoamyl alcohol $(24: 1)$. The samples were mixed well by vortex and then centrifuged at $4,500 \mathrm{rpm} 4{ }^{\circ} \mathrm{C}$ for $10 \mathrm{~min}$. The aqueous phase was collected in a new $1.5 \mathrm{~mL}$ microcentrifuge tube, and $8 \mathrm{M} \mathrm{LiCl}$ was added to a final concentration of $2 \mathrm{M} \mathrm{LiCl}$ in each tube and inverted gently 2 - 3 times. The mixture was stored at $4{ }^{\circ} \mathrm{C}$ overnight for RNA precipitation. The precipitated RNA was centrifuged at $13,000 \mathrm{rpm}$ for $30 \mathrm{~min}$ at $4^{\circ} \mathrm{C}$, and the supernatant was discarded on the following day. The precipitated RNA was washed with $1 \mathrm{~mL}$ of $70 \%$ cool ethanol and centrifuged at $13,000 \mathrm{rpm} 4{ }^{\circ} \mathrm{C}$ for $10 \mathrm{~min}$. Ethanol was removed, and the pellet was allowed to air dry at room temperature. The air-dried RNA pellets were resuspended in $20 \mathrm{~mL}$ of DEPC-treated H2O. The first strand cDNA was synthesized from $5 \mathrm{mg}$ of total RNA, using SuperScriptTM III First-Strand Synthesis 
http://wjst.wu.ac.th

System for RT-PCR kit (Cat\#18080-051, Invitrogen Life Technologies, USA) according to the manufacturer's instruction.

\section{Qualitative RT-PCR analysis}

The first strand cDNA was diluted 10 times with $\mathrm{H}_{2} \mathrm{O}$, and then used as templates for gene expression analysis. The pair of forward and reverse primers specific primers $\left(5^{\prime}-3^{\prime}\right)$ for $G m-18 S r R N A$; TTGGTGTGCACCTGTCATCT and TCATTACTCCGATCCCGAAG (accession number EU032463), Gm-ACS; AGGAAAGCCTTGGAAGAAGC and GGACCTGAAGACCGTAGCTG (accession number HQ197954) and $G m-A C O$; CATGGATGAAATCCCTGACC and TAGGGCATGGAG GGTACTTG (accession number HQ197955), GmETR; GAGAGGTGGTTGGTGTTCGT and AGAAGATCCCTTGCCCT CAT (Palapol, Y., personal communication), were designed by Primer3 (http://simgene.com/Primer3). The mangosteen $18 \operatorname{SrRNA}$ gene was used as internal control. Three replications were conducted. Gene expression was analyzed by real time qPCR, using CFX96 Touch ${ }^{\mathrm{TM}}$ Real-Time PCR machine and SYBR green (iTaqTM Universal SYBR Green Supermix (Bio-Rad Laboratories Ltd., USA). The obtained CT values were analyzed with the CFX manager ${ }^{\mathrm{TM}}$ software by averaging 3 independently calculated normalized expression values for each sample. Expression values are given as the mean of the normalized expression values of the triplicates.

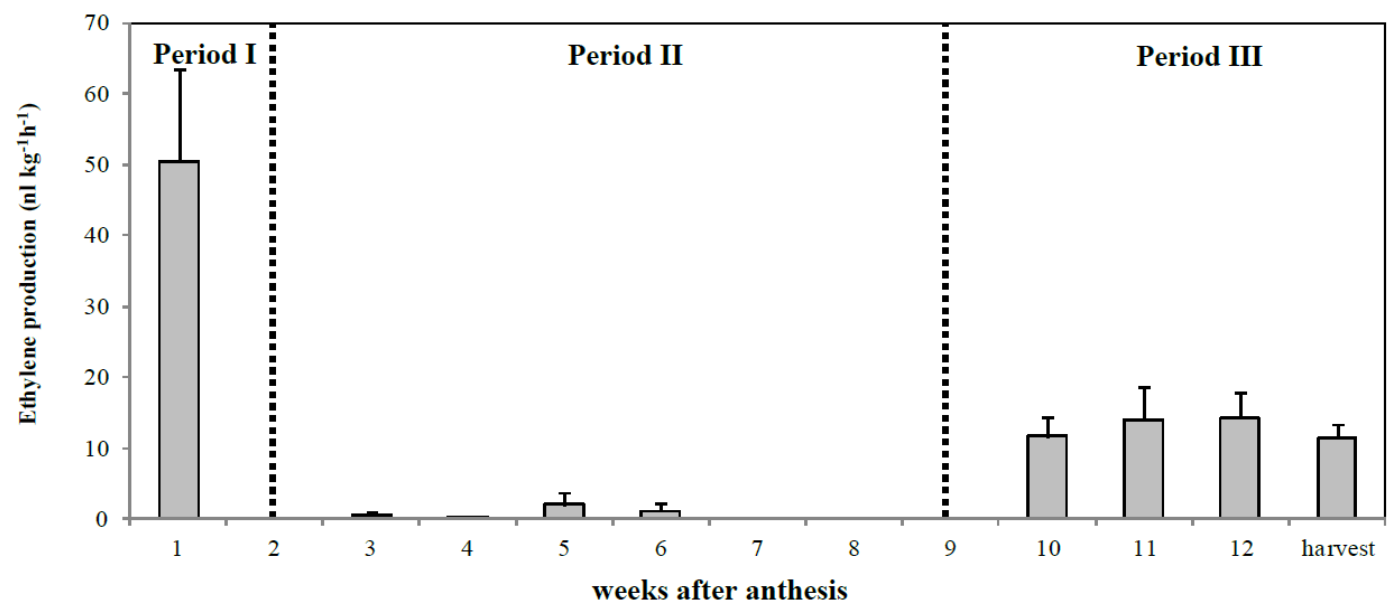

Figure 1 Ethylene production during fruit development from the flower blooming until harvest fruit at stage 1 (pericarp light greenish yellow with 5 - $50 \%$ scattered pinkish spots); fruit set (Period I), fruit development (Period II) and fruit maturation and ripening (Period III). Error bars indicate triplicates of standard error of means.

\section{Results and discussion}

The expression pattern of ethylene biosynthesis and perception genes during mangosteen fruit development

The mRNA levels of Gm-ACS, Gm-ACO and Gm-ETR genes varied markedly between different developmental periods based on Figure 1. The transcript of Gm-ACS was expressed at a relatively low level at early stages and was fairly stable during mangosteen development until age 10 weeks, stage 0 ; pericarp uniformly yellowish-white or with a light green tinge or grayish spotting. Then, Gm-ACS expression increased sharply at fruit age 11 - 12 weeks, but levels were not-detected at harvest stage 1 (Figure 2a). A high-level Gm-ACO transcript was detected at the fruit set's onset, and its abundance decreased to a low-level during fruit development. Gm-ACO was found to increase at the maturation and 
ripening stage again but to be lower than at the fruit set and early development. Finally, Gm-ACO was expressed at the lowest level at harvest stage 0 (Figure 2b). The relative expression of Gm-ETR was very high at fruit age $1-2$ weeks after fruit set, and then declined continuously at fruit age 3 - 9 weeks or during fruit development, and increased slightly at 2 weeks before harvest and declined to non-detected levels at harvest stage (Figure 2c).
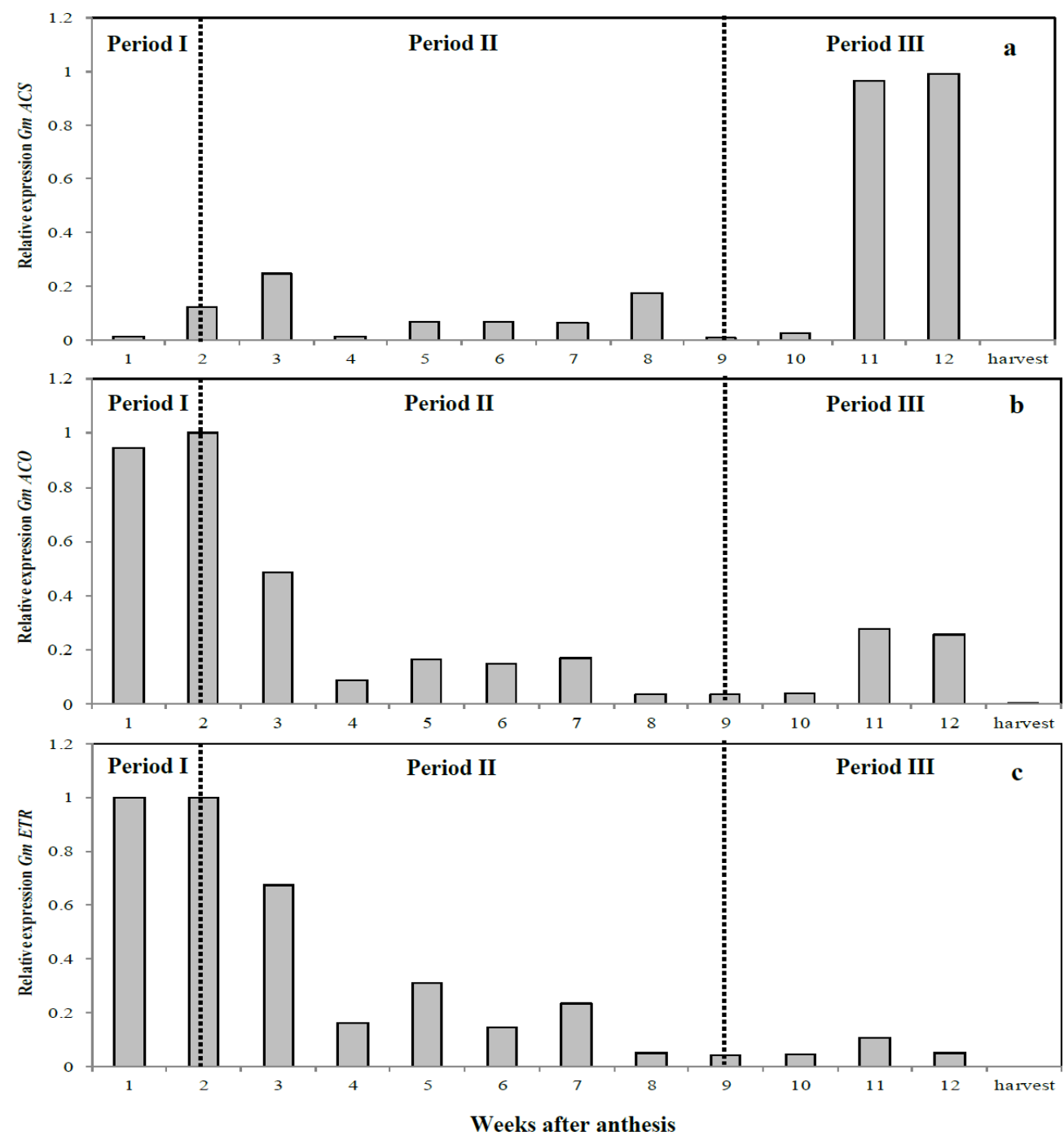

Figure 2 Expressions of mangosteen ethylene biosynthesis genes; (a) Gm-ACS and (b) GmACO and perception; (c) Gm-ETR, during fruit development from the flower blooming until harvest fruit at stage 1 (pericarp light greenish yellow with 5 - $50 \%$ scattered pinkish spots); fruit set (Period I), fruit development (Period II) and fruit maturation and ripening (Period III). Error bars indicate triplicates of standard error of means. 
Previously, evidence of climacteric of mangosteen occurs before harvest; expected time of climacteric was in fruit at stage 0 , which coincides with approximately 10 weeks after fruit set, in the geographical areas' cultivation conditions the trees from which fruits were harvested [5]. In this study, it seems only Gm-ACO is expressed at a higher level than Gm-ACS in parallel with ethylene production levels during fruit development and mangosteen ripening. The transcript of Gm-ACO was expressed concomitantly with ethylene production levels of mangosteen fruit during a sigmoid growth based on fruit weight. This expression of Gm-ACO is responsible both for operating to produce a trace amount of ethylene during fruit set (Period I) and development (Period II) and for the burst of ethylene production during fruit ripening (Period III). At the same time, Gm-ACS is only expressed abundantly at Period III.

The results showed that Gm-ACO expression was more closely correlated with a climacteric pattern of ethylene production as previous study [6]. The expression of Gm-ACO confirmed the major role of ACO enzyme during mangosteen development and ripening [13].

However, unlike in apple fruit (Malus $\times$ domestica Borkh.), ACS is the rate-limited enzyme and plays the most important role in the ripening stage [14]. Pech [15] have been reported that a multigene family encodes both ACS and ACO genes in most fruit. Apple is a well-known climacteric fruit and a model system to study the ripening process of perennial fruit trees; therefore, data of ethylene biosynthesis and perception in apple made a large contribution to molecular study. They identified the 19 sequences of ACS genes and found that the 6-member genes were expressed.

Besides, ETR1, the perception gene, was the $1^{\text {st }}$ protein to be definitively assigned the role of hormone receptor in plants, and both genetic and biochemical data confirm that ETR1 encodes an ethylene receptor [16]. This study's transcript results showed differences in expression levels of ethylenerelated genes not only Gm-ACO but also Gm-ETR, which is connected with ethylene perception.

However, the expression trend of Gm-ETR was expressed highly at fruit set (Period I) and gradually decreased during fruit development and maturation, Period II and III, respectively. The reason partially explained this is that Gm-ETR is the multigene families, which play a role in controlling mangosteen ripening during fruit development and ripening. However, the submission data of ethylene-related genes of mangosteen in GenBank was available only in limited genes, Gm-ACS (Accession Number: HQ197954) and Gm-ACO (Accession Number: HQ197955).

Therefore, further studies must be done in mangosteen fruit to identify the specific genes of ethylene signaling transduction and biosynthetic pathways specific to each developmental process at the ripening stage.

\section{The effects of preharvest ethephon or 1-MCP treatment on expression of ethylene biosynthesis and perception genes}

Preharvest ethephon application accelerated the early onset of ripening by $1-2$ days when applied at stage 0 . In contrast, 1-MCP fumigation was effective in delaying ripening by 11 days [5]. Ethephon treatment at or beyond $24 \mathrm{~h}$ (threshold time) increased the mRNA levels of all 3 genes, Gm-ACS, Gm$\mathrm{ACO}$, and Gm-ETR. In contrast, 1-MCP treatment under the threshold time significantly inhibited expression resulting in non-detectable mRNA in both ethylene biosynthesis and receptor genes. On harvest date, the result of real-time qPCR showed a large decrease, especially in Gm-ACS expression in ethylene-treated mangosteen when compared with the transcript at the end of ethylene treatment.

On the other hand, an increase in the abundance of the Gm-ACS, Gm-ACO and Gm-ETR gene was observed in 1-MCP-treated fruits. Also, Gm-ACS expression was lowest, while the Gm-ACO and GmETR were up-regulated to higher levels. Interestingly, each gene's relative expression pattern at the harvest date was similar between ethephon and 1-MCP treatments (Figure 3).

Harvest stage fruit showed down-regulation at the lowest level of the Gm-ACO expression. Ethephon treatment at or beyond $24 \mathrm{~h}$ (threshold time) increased the mRNA levels of Gm-ETR, Gm-ACS and Gm-ACO. In contrast, 1-MCP treatment under the threshold time caused undetectable expression in all ethylene-related genes. This also related to the expression of $\mathrm{Gm}-\mathrm{ACO}$ in mangosteen fruit in response to exogenous ethylene and 1-MCP. The results showed that the regulation of Gm-ACO is expressed after ethephon treatments. This may be interpreted that ACO is a dominant limiting enzyme of ethylene 
http://wjst.wu.ac.th

biosynthesis in mangosteen ripening. In contrast, 1-MCP treatment under the threshold time caused undetectable expression in all ethylene-related genes.
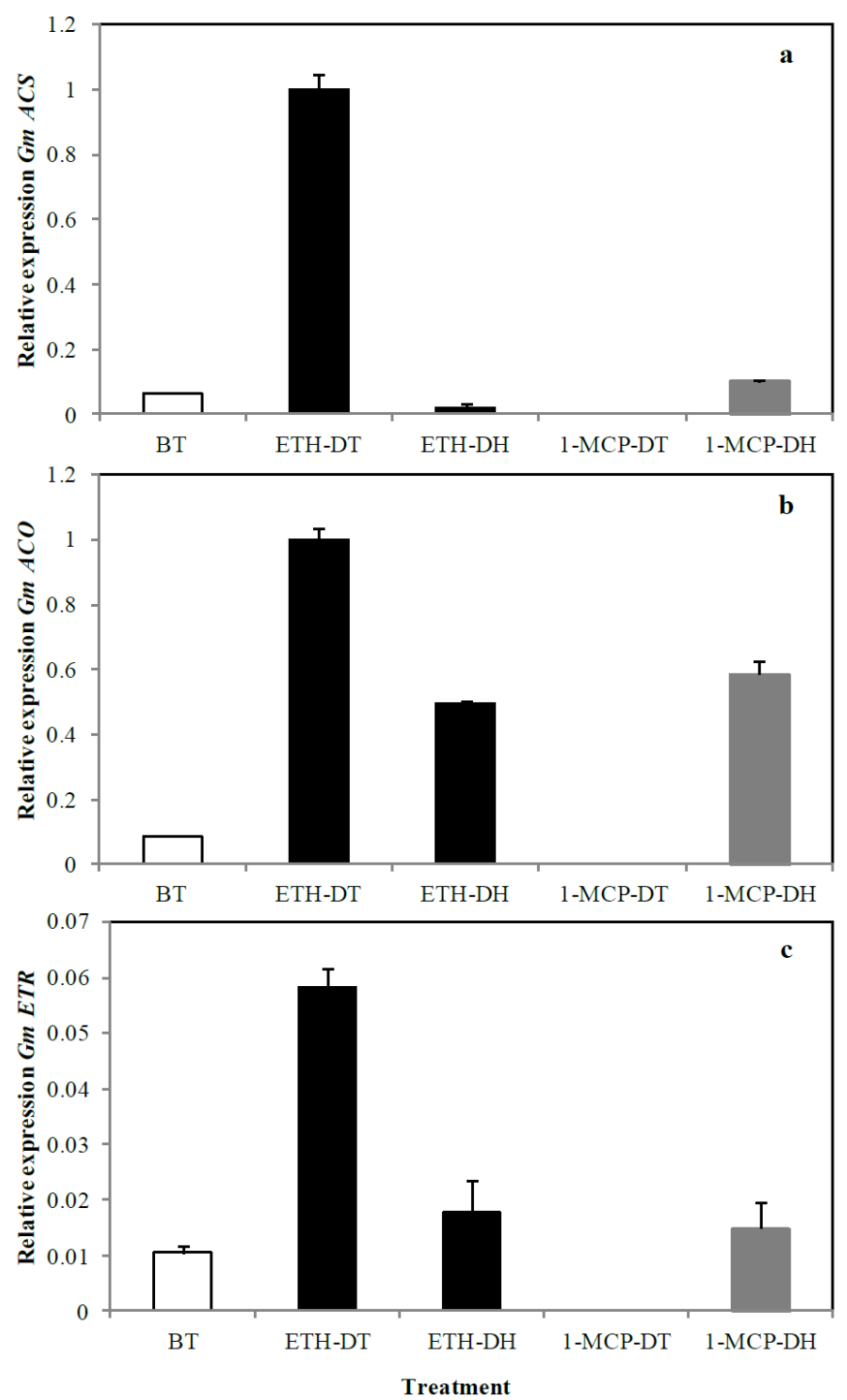

Figure 3 Expressions of mangosteen ethylene biosynthesis genes; (a) GmACS, (b) GmACO and perception; (c) GmETR, after preharvest application of ethephon and 1-MCP at fruit stage 0; pericarp uniformly yellowish-white or with a light green tinge or grayish spotting. Error bars indicate triplicates of standard error of means. Abbreviation; BT = before treatment, ETH-DT = application date of ethephon treatment, ETH-DH = harvest date of ethephon treatment, 1-MCP-DT = application date of 1-MCP treatment and 1-MCP-DH $=$ harvest date of 1-MCP treatment. 
http://wjst.wu.ac.th

1-MCP, an antagonist of ethylene receptor, is reported to extend mangosteen's storage life and shelf life [16]. Also, preharvest application of 1-MCP at pre-climacteric fruits delayed its harvest date [5]. This demonstrated that a suitable way to control mangosteen's ripening should be at the level of ethylene signal transduction. However, Li et al. [17] have reported that 1-MCP totally inhibited these 6 ACS genes' expressions. The rest of the ACS genes did not respond to 1-MCP during the stage of young fruit. In the case of mangosteen, however, the inhibition mechanism of 1-MCP in ripening and ethylene biosynthesis was not elucidated with exiting results.

\section{Conclusions}

This study is the $1^{\text {st }}$ to investigate the expression of ethylene biosynthetic and perception genes in detached mangosteen throughout the stage of fruit development and fruit set to harvest. The results confirmed the Gm-ACO is the major gene in the rate-limiting step of ethylene production during fruit ripening. Preharvest application of ethephon or 1-MCP can induce or inhibit the gene expression of ethylene biosynthesis and mangosteen perception.

\section{Acknowledgements}

We gratefully acknowledge the Office of the Higher Education Commission (OHEC), the Thailand Research Fund (TRF) and the Postharvest Technology Innovation Center (PHTIC) for financial support.

\section{References}

[1] RE Paull and O Duarte. Tropical Fruits, Vol II. CAB International, Wallingford, 2012, p. 123-38.

[2] Office of Agricultural Economics. Thailand Foreign Agricultural Trade Statistics. Ministry of Agriculture and Cooperative, Thailand. Available at: http://www.oae.go.th/assets/portals/1/files/ jounal/2562/yearbook2561-13-3-62.pdf, accessed January 2019.

[3] A Abdul-Rahman, HH Goh, KK Loke, NM Noor and WM Aizat. RNA-seq analysis of mangosteen (Garcinia mangostana L.) fruit ripening. Genom. Data 2017; 12, 159-60.

[4] AAR Parijadi, SP Putri, S Ridwani, FM Dwivany and E Fukusaki. Metabolic profiling of Garcinia mangostana (mangosteen) based on ripening stages. J. Biosci. Bioeng. 2018; 125, 238-44.

[5] L Lerslerwong, A Rugkong, W Imsabai and S Ketsa. The harvest period of mangosteen fruit can be extended by chemical control of ripening: A proof of concept study. Sci. Hort. 2013; 157, 13-8.

[6] M Liu, J Pirrello, C Chervin, JP Roustan and M Bouzayen. Ethylene control of fruit ripening: Revisiting the complex network of transcriptional regulation. Plant Physiol. 2015; 169, 2380-90.

[7] Y Palapol, S Ketsa, D Stevenson, JM Cooney, AC Allan and IB Ferguson. Colour development and quality of mangosteen (Garcinia mangostana L.) fruit during ripening and after harvest. Postharvest Biol. Technol. 2009; 51, 349-53.

[8] S Lurie. Manipulating Fruit Development and Storage Quality Using Growth Regulators. In: AS Basra (Ed.). Plant Growth Regulators in Agriculture and Horticulture: Their Role and Commercial Uses. Food Products Press, London, 2000, p. 175-96.

[9] G Ferrara, A Mazzeo, AMS Matarrese, C Pacucci, A Trani, MW Fidelibus and G Gambacorta. Ethephon as a potential abscission agent for table grapes: Effects on pre-harvest abscission, fruit quality and residue. Front. Plant Sci. 2016; 7, 1-7.

[10] SM Blankenship and JM Dole. 1-Methylcyclopropene: A review. Postharvest Biol. Tech. 18, 1-25.

[11] FB Abeles, PW Morgan and Jr ME Saltveit. Ethylene in Plant Biology. Academic Press, New York, 1992, p. 414.

[12] J Giovannoni. Molecular biology of fruit maturation and ripening. Annu. Rev. Plant Physiol. Plant Mol. Biol. 2001; 52, 725-49.

[13] P Piriyavinit, S Ketsa and WG van Doorn. 1-MCP extends the storage and shelf life of mangosteen (Garcinia mangostana L.) fruit. Postharvest Biol. Technol. 2011; 61, 15-20.

[14] T Li, D Tan, X Yang and A Wang. Exploring the apple genome reveals six ACC synthase genes expressed during fruit ripening. Sci. Hort. 2013; 157, 119-23. 
http://wjst.wu.ac.th

[15] JC Pech, A Latché and M Bouzayen. Ethylene Biosynthesis. In: PJ Devies (Ed.). Plant Hormone: Biosynthesis, Signal Transduction, Action. $3^{\text {rd }}$ ed. Kluwer Academic Publisher, London, 2004, p. 115-36.

[16] S Klee and RE Paull. Ethylene Signal Transduction in Fruits and Flowers. In: PJ Devies (Ed.). Plant Hormone: Biosynthesis, Signal Transduction, Action. $3^{\text {rd }}$ ed. Kluwer Academic Publisher, London, 2004, p. 369-90. 